\author{
A. Polyvianchuk ${ }^{1}$, S. Romanenko ${ }^{1}$, R. Semenenko ${ }^{1}$, L. Semenenko ${ }^{2}$, K. Yeskova ${ }^{1}$ \\ ${ }^{1}$ O.M. Beketov National University of Urban Economy in Kharkiv, Ukraine \\ ${ }^{2}$ National Technical University «Kharkiv Polytechnic Institute», Ukraine
}

\title{
COMPLEX ASSESSMENT OF THE ENERGY-SAVING MEASURES EFFECTIVENESS IN THE FIELD OF HEAT SUPPLY OF EDUCATIONAL INSTITUTIONS
}

The work is devoted to solving an urgent scientific problem - increasing the informativeness of methods for assessing the effectiveness of energy saving measures in the areas of heat supply and heat consumption. The purpose of the research was to create and implement a method for multicriteria evaluation of the effectiveness of energysaving measures for the thermal energy of buildings. The following indicators are used as criteria for assessing the effectiveness of the studied measures in this method: 1) energy effect - the absolute and relative value of the saved thermal energy; 2) environmental effect - the amount of fuel saved, reducing emissions of greenhouse gases and pollutants into the atmosphere; 3) economic effect - the cost of saved thermal energy and fuel. The practical implementation of the created method was carried out on the basis of 2 full-scale objects: No. 1 - a 3-story fragment of the administrative building of Kharkov National University of Municipal Economy them. A.N. Beketova with a total heated area of $225 \mathrm{~m}^{2}$ and No. 2 - the building of the communal institution "Kharkov Palace of Children and Youth Creativity" with a total heated area of more than $13700 \mathrm{~m}^{2}$. For full-scale object No. 1, the effectiveness of using "smart home» technology to control the thermal conditions of the building's premises using the HERZ Smart Comfort automated system has been evaluated. For full-scale object No. 2 was evaluated the effectiveness of 2 energysaving measures: controlling the thermal conditions of the building's premises with the HERZ Smart Comfort system and using an alternative heat source - heliosystem, which consists of 180 solar collectors. The research results showed such properties of the proposed method for evaluating the effectiveness of energy-saving measures, such as: high information content of the results, providing the possibility of multicriteria optimization of the parameters of heat supply systems and heat consumption of the research object, ability to improve by increasing the number of studied performance indicators.

Keywords: heat supply, heated area, energy saving measures, efficiency, complex assessment, natural object, educational institution.

\section{Introduction}

In recent years, a significant number of cities in Ukraine, in particular, Kyiv, Kharkiv, Lviv, Ternopil, Chernivtsi and others. have joined the Covenant of Mayors on Climate and Energy [1], which provides for the holding municipal authorities measures to significantly reduce greenhouse gas emissions by $30 \%$ by 2030. Achieving this result requires a new strategy for the use and development of the municipal energy system, which envisages increasing the environmental safety of boiler plants and thermal power plants through the introduction of innovative high-efficiency energysaving, environmental and economically sound technologies [2]. This strategy should take into account such problems of the Ukrainian economy as: outdated technologies and equipment for thermal energy production, high energy consumption and material costs exceeding 2-3 times the corresponding indicators of developed countries; lack of modern environmental protection systems, lack of appropriate legal and economic mechanisms that would encourage the development of environmentally friendly technologies, environmental protection techniques, etc. [3]. At the same time, stimulating the effective consumption of thermal energy by users will allow reduce the resource consumption of urban heating networks, which will reduce environmental pollution and reduce greenhouse gas emissions.

Actual scientific task that confronts the communal sector of the economy today is to increase the informative methods for assessing the effectiveness of measures energy saving in the areas of heat supply and heat consumption. To solve this problem, the effectiveness of the measures under study should be considered as a complex value, which takes into account the energy, environmental and economic consequences of their implementation.

\section{The purpose and objectives of the study}

The purpose of this work was to create and practical implementation method of multicriteria assessment of the effectiveness of energy saving measures with thermal energy of buildings by indicators of energy, environmental and economic effects. To achieve this 
goal, the following tasks were solved: 1) the creation of a multi-criteria method for evaluating the effectiveness of energy conservation measures in the field of heat supply; 2) realization of the created method for assessing the effectiveness of energy-saving measures recommended for implementation at full-scale facilities.

\section{Analysis of recent research and publications}

Recently, the interaction between energy and the environment has become dangerous character. Burning and heat energy installations carry out chemical pollution of the environment by emissions of harmful substances, first of all nitrogen and sulfur oxides, greenhouse gas emissions - $\mathrm{CO}_{2}, \mathrm{CO}$ those others, ash and soot emissions, which are steadily exacerbating environmental problems due to incareased production.

The growing technogenic burden on the environment and the exacerbation of these environmental security issues require an immediate change in environmental policy and the sustainable development of ecology in the future, energy and the economy. The solution to this problem is made possible by a clear optimization of the structure of the energy balance of the country, in which the largest share should be ecologically safe energy sources from renewable energy sources.

Traditional energy today accounts for at least $30 \%$ of all atmospheric emissions. Of the total emissions, about $30 \%$ are solids, more than $60 \%$ sulfuric anhydride, and about $55 \%$ nitrogen oxides. In these conditions, the integration of energy and ecology, close interrelation of ecological aspects of energy with energy aspects of ecology is important in the region [4]. The implementation of such integration is in accordance with the concept of sustainable development of society, whose main purpose is to ensure the high quality of life of present and future generations on the basis of a balanced solution to the problems of economic development, conservation of the natural environment, rational use and reproduction of the planet's natural resource potential.

An analysis of the development strategy of the EU energy sector shows that between 2020 and 2030, the relative shares in the energy balance of primary energy sources of fuels such as oil and solid fuels will decrease by $0.4 \%$ (from 35.7 to $35.3 \%$ ) ) and $0.7 \%$ (from 17.4 to $16 \%$ ), respectively, of natural gas - will not change $25.7 \%$, and the share of renewable energy sources will increase by $3.1 \%$ (from $9.9 \%$ to $12.0 \%$ ). Thus, the contribution to the energy balance of traditional energy sources will be reduced over the years, which will lead to an increase in their cost, while, on the contrary, renewable energy sources will increase significantly [5].

One of the promising areas of energy resource conservation is the utilization of solar energy due to the depletion of world oil and gas reserves, as well as the problem of environmental pollution by solid fuel combustion products. The technology of utilization of solar energy, which is most prepared for the implementation of public utilities needs, is water heating by solar energy. Ukraine's National Energy Strategy for the period up to 2030 envisages a gradual increase in the production of equipment for solar hot water supply and heating systems, and it is also planned to install about 2 million $\mathrm{m}^{2}$ of solar collectors, which will allow to obtain tangible savings. Experience in operating these systems has shown that $1 \mathrm{~m}^{2}$ of solar collector under optimal operating conditions saves from 0.1 to 0.15 tons of conditional fuel during the summer season. Large-scale use of solar systems in Ukraine by 2030 will save up to 200 thousand within the adopted strategy of energy industry development Tons of conditional fuel [6].

\section{Presentation of the main material}

The method of multi-criteria evaluation of the effectiveness of energy-saving measures. The essence of this method is that the overall effectiveness of energy-saving measures is considered as a 3-component vector $\mathrm{E}$, components of which are energy $-\mathrm{E}_{\mathrm{I}}$, environmental $-\mathrm{E}_{\mathrm{II}}$ and economic - $\mathrm{E}_{\mathrm{III}}$ effects of their implementation At the same time, the following indicators are used to assess these components of overall efficiency:

- for energy effect $E_{I}$ : absolute $-\Delta \mathrm{Q}(\mathrm{kW} \cdot \mathrm{h})$ and relative $-\delta \mathrm{Q}(\%)$ value of the saved amount of thermal energy for the heating period, which are determined as:

$$
\Delta \mathrm{Q}=\mathrm{Q}_{\mathrm{tot1}}-\mathrm{Q}_{\mathrm{tot} 2}
$$

where $\mathrm{Q}_{\text {tot1 }}$ and $\mathrm{Q}_{\text {tot2 }}$ are the total heat losses due to the building enclosure during the heating period before and after the implementation of energy-saving measures, respectively, kWh;

$$
\delta \mathrm{Q}=\frac{\mathrm{Q}_{\text {tot1 }}-\mathrm{Q}_{\text {tot2 }}}{\mathrm{Q}_{\mathrm{tot} 1}} \cdot 100 \% ;
$$

- for environmental effect $E_{I I}$ : mass (volume) of fuel saved $-\Delta \mathrm{M}_{\text {fuel }}(\mathrm{kg})\left(\Delta \mathrm{V}_{\text {fuel }}\left(\mathrm{m}^{3}\right)\right)$, reduction of mass of greenhouse gas emissions, in particular - of $\mathrm{CO}_{2}$ and pollutants $-\Delta \mathrm{M}_{\mathrm{p}}(\mathrm{kg})$ :

$$
\Delta \mathrm{M}_{\text {fuel }}=3,6 \cdot \frac{\Delta \mathrm{Q}}{\mathrm{Q}_{1}},
$$

where $\mathrm{Q}_{1}$ - the lower heat of combustion of the fuel, $\mathrm{MJ} / \mathrm{kg}$;

$$
\Delta \mathrm{V}_{\text {fuel }}=\frac{\Delta \mathrm{M}_{\text {fuel }}}{\rho_{\text {fuel }}},
$$

where $\rho_{\text {fuel }}-$ density of fuel, $\mathrm{kg} / \mathrm{m}^{3}$;

$$
\Delta \mathrm{M}_{3 \mathrm{P}}=3,6 \cdot 10^{-3} \cdot \mathrm{K}_{\mathrm{P}} \cdot \Delta \mathrm{Q},
$$

where $\mathrm{K}_{\mathrm{P}}$ - coefficient pollutant emissions [7], g/GJ;

- for economic effect $E_{I I I}$ : reduction of payment for the amount of heat consumed during the heating period $-\Delta \mathrm{C}_{\mathrm{hc}}(\mathrm{UAH})$ and for fuel $-\Delta \mathrm{C}_{\text {fuel }}(\mathrm{UAH})$ :

$$
\Delta \mathrm{C}_{\mathrm{hc}}=9,6 \cdot 10^{-4} \cdot \mathrm{c}_{\mathrm{hc}} \cdot \Delta \mathrm{Q} \text {, }
$$

where $c_{h c}$ - the cost of a unit of thermal energy according to the set tariffs, UAH/Gcal; 


$$
\Delta \mathrm{C}_{\text {fuel }}=10^{-3} \cdot \mathrm{c}_{\text {fuel }} \cdot \Delta \mathrm{V}_{\text {fuel }} \text {, }
$$

where $c_{\text {fuel }}-$ the cost of fuel according to the set tariffs, $\mathrm{UAH} /$ ton or $\mathrm{UAH} /$ ths. $\mathrm{m}^{3}$.

Description of the objects of research. As fullscale object No. 1 a fragment of the administrative building was chosen for research O.M. Beketov National University of Urban Economy in Kharkiv (O.M. Beketov NUUE), in which are located: a lecture hall, a laboratory, a conference hall and offices of the university administration. This is a three-story building with two external walls and two internal walls adjacent to heated rooms with a total heated area of $225.3 \mathrm{~m}^{2}$ (Fig. 1). For full-scale object No.1 recommended use smart home technology for control thermal modes building premises using the HERZ Smart Comfort automated system [8].

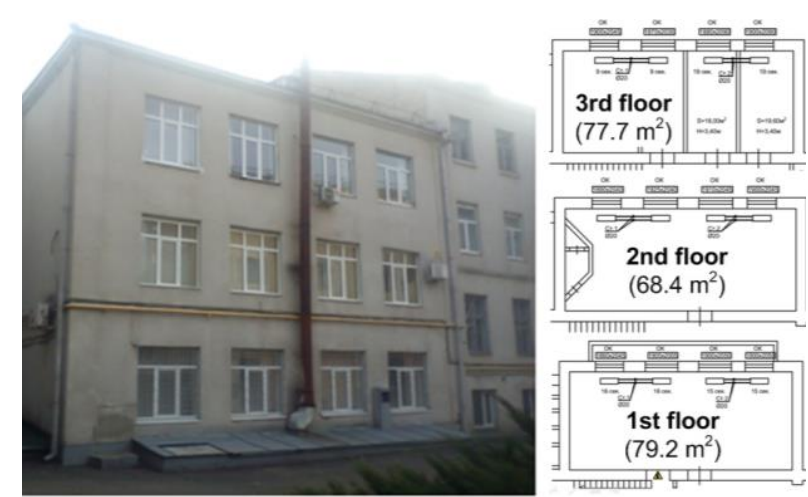

Fig. 1. Full-scale object No. 1 for studying

As a full-scale object No. 2 for research was chosen the building of the Communal Institution «Kharkov Palace of Children and Youth Creativity» (CI KhPCYC) 1993 of the building, which consists of two buildings and has a multi-level complex T-shape (Fig. 2). According to the project documentation for the building: its construction volume is $80375 \mathrm{~m}^{3}$, the total area of the building is $15159 \mathrm{~m}^{2}$; usable area $13712 \mathrm{~m}^{2}$; the projected consumption of thermal energy for heating $1 \mathrm{~m}^{2}$ of the total area is $183 \mathrm{~W} / \mathrm{m}^{2}$.
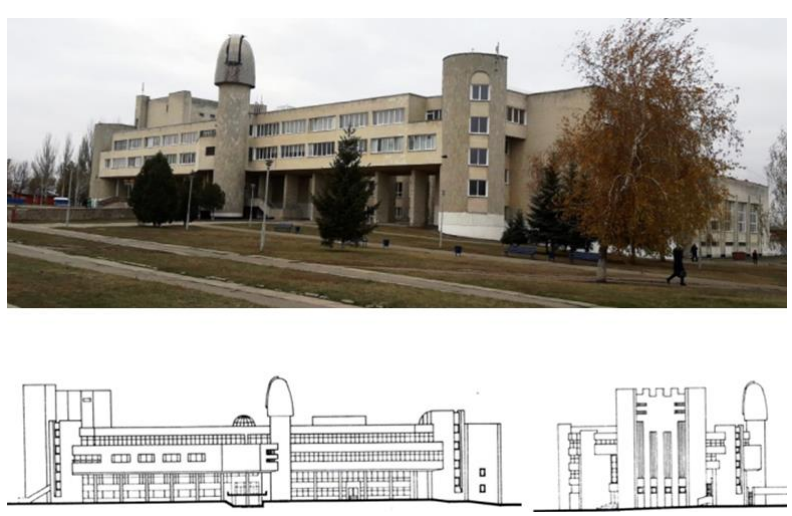

Fig. 2. Full-scale object No. 2 for studying

For full-scale object No. 2, the use of 2 energysaving measures is recommended: controlling the ther- mal conditions of the building's premises with the HERZ Smart Comfort system and using an alternative source of heat supply - heliosystems. The shape of the possible location of the heliosystems with a total area of $1080 \mathrm{~m}^{2}$ is located on the south side of one of the buildings of the CI KhPCYC. On the recommended site in accordance with established requirements 180 flat-type solar collectors of the recommended type [9] - Buderus (Germany) SKT 1.0 can be placed.

\section{Research results and their analysis}

Evaluation of the energy-saving measures effectiveness at full-scale object No. 1. Indicators of energy efficiency from the use of the system of regulation of thermal modes of premises of object were determined by the formulas (without taking into account the thermal inertia of the building):

$$
\begin{aligned}
& \delta \mathrm{Q}=\left(1-\gamma_{\text {comf }}\right) \cdot \frac{\mathrm{t}_{\text {in }}^{\text {comf }}-\mathrm{t}_{\text {in }}^{\text {econ }}}{\mathrm{t}_{\text {in }}^{\text {comf }}-\mathrm{t}_{\text {out }(\mathrm{a})}} \cdot 100 \%= \\
& =(1-0.16) \cdot \frac{20-16}{20-(-0.8)} \cdot 100 \%=17 \%
\end{aligned},
$$

where $\gamma_{\text {comf }}$ - indicator of the building's relative need for comfortable heat supply; $\mathrm{wt}_{\text {out(a) }}=-0.8^{\circ} \mathrm{C}$ - average air temperature in Kharkiv for the heating period 2019;

$$
\begin{aligned}
& \Delta \mathrm{Q}=\left(\mathrm{q} \cdot \mathrm{S}_{\mathrm{ha}}\right) \cdot \frac{\delta \mathrm{Q}}{100} \cdot 10^{3}= \\
& =(97,5 \cdot 225,3) \cdot \frac{17}{100}=3734, \mathrm{~kW} \cdot \mathrm{h},
\end{aligned}
$$

where $\mathrm{q}=97.5(\mathrm{~kW} \cdot \mathrm{h}) / \mathrm{m}^{2}$ is the actual specific heat consumption of the administrative building of O.M. Beketov NUUE in 2019 year.

According to formulas (4) - (7), the indicators of environmental and economic effects from the implementation of the energy saving measure for the heating period were determined, which were: reduction of natural gas consumption for heating $-\Delta \mathrm{V}_{\text {fuel }}=406.4 \mathrm{~m}^{3}$; reduction of $\mathrm{CO}_{2}$ and $\mathrm{NO}_{\mathrm{x}}$ emissions into the atmosphere $-\Delta \mathrm{M}_{\mathrm{CO} 2}=789.1 \mathrm{~kg} ; \Delta \mathrm{M}_{\mathrm{NOx}}=0.86 \mathrm{~kg}$; reduction of the payment for the use of thermal energy and fuel $\Delta \mathrm{C}_{\mathrm{hc}}=4441 \mathrm{UAH}$ and $-\Delta \mathrm{C}_{\text {fuel }}=4041 \mathrm{UAH}$.

Evaluation of the energy-saving measures effectiveness at full-scale object No. 2. Based on the above ratios estimated the level of saved heat energy in all rooms of the CI KhPCYC building, which require optimization of the temperature regime. The calculation results (Fig. 3) indicate that the use of optimizing the temperature mode of the building by lowering the temperature during the absence of staff and visitors can save 130.3 Gcal or $11.1 \%$ of heat energy during the heating season. Moreover, the relevant indicators of environmental and economic effects are: reduction of natural gas consumption -16.5 thousand $\mathrm{m}^{3}$, reduction of $\mathrm{CO}_{2}$ and $\mathrm{NO}_{\mathrm{x}}$ emissions into the atmosphere - 32.0 tons and 0.035 tons, respectively; reduction in heating charges -249.5 thousand UAH. 


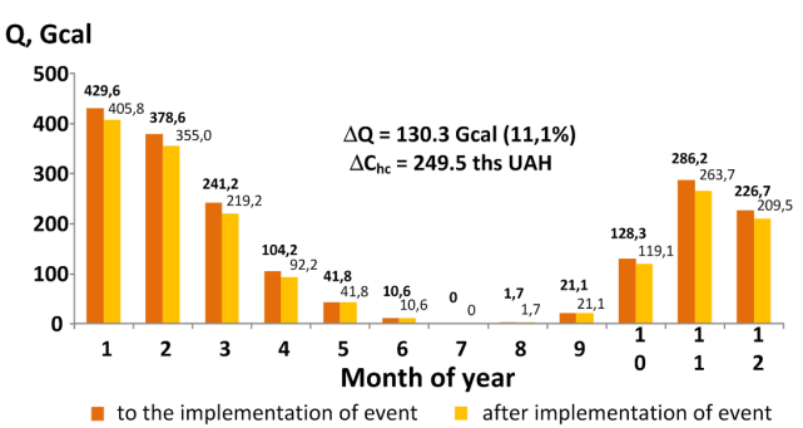

Fig. 3. The results of evaluating the efficiency of use

HERZ Smart Comfort system at the object No. 2

A multicriteria assessment of the efficiency of use of the heliosystem shows that this measure allows you to additionally obtain such an annual effect: energy - an additional amount of thermal energy - 376.7 Gcal or $20.2 \%$, of which it can be used: the building of the communal enterprises CI KhPCYC - 212.3 Gcal or 11.4 $\%$, in other buildings (from May to September) - 164.4 Gcal or $8.8 \%$; In this case, the demand of communal enterprises CI KhPCYC in thermal energy is provided: in the period from May to September - by $100 \%$, in the heating period - by $2.8 \ldots 35.6 \%$; ecological - reduction of natural gas consumption -47.7 thousand $\mathrm{m}^{3}$, reduction of $\mathrm{CO}_{2}$ and $\mathrm{NO}_{\mathrm{x}}$ emissions - 92.6 tons and 0.101 tons, respectively; economic: reduction of payment for thermal energy - 721.3 thousand UAH; The payback period of the event is 5 years.

\section{Conclusions}

1. Created a method of multicriteria performance evaluation of the effectiveness of energy-saving measures for the thermal energy of buildings. The following indicators are used as criteria for assessing the effectiveness of the studied measures in this method: 1) energy effect - the absolute and relative value of the saved thermal energy; 2) environmental effect - the amount of fuel saved, reducing emissions of greenhouse gases and pollutants into the atmosphere; 3) economic effect - the cost of saved thermal energy and fuel.

2. The practical realization of the created method on the basis of 2 full-scale objects: No. 1 - a 3-story fragment of the administrative building of O.M. Beketov National University of Urban Economy in Kharkiv with a total heated area of $225 \mathrm{~m}^{2}$ and No. 2 the building of the Communal Institution «Kharkov Palace of Children and Youth Creativity» with a total heated area of more than $13700 \mathrm{~m}^{2}$.

3. For full-scale object No. 1, the effectiveness of using «smart home» technology to control the thermal conditions of the building's premises using the HERZ Smart Comfort automated system has been evaluated. The following performance indicators for the use of this measure for the heating period are thermal energy savings $-3734 \mathrm{kWh}$ or $17 \%$, reduction of natural gas con- sumption for heating - $406.4 \mathrm{~m}^{3}$, reduction of $\mathrm{CO}_{2}$ and $\mathrm{NO}_{\mathrm{x}}$ emissions $-789.1 \mathrm{~kg}$ and $0.86 \mathrm{~kg}$, respectively reduction of payment for consumption of thermal energy - $4041 \mathrm{UAH}$ and fuel - $4441 \mathrm{UAH}$.

4. For full-scale object No. 2 was evaluated the effectiveness of 2 energy-saving measures: controlling the thermal conditions of the building's premises with the HERZ Smart Comfort system and using an alternative heat source - heliosystem, which consists of 180 solar collectors. It was established that the 1 -st event has such an annual effect: energy - 130,3 Gcal or $11.1 \%$; ecological: reduction of natural gas consumption -16.5 thousand $\mathrm{m}^{3}$, reduction of $\mathrm{CO}_{2}$ and $\mathrm{NO}_{\mathrm{x}}$ emissions into the atmosphere -32.0 tons and 0.035 tons, respectively; economic: reduction of payment for searing - 249.5 thousand UAH; 2-nd event has such an annual effect: energy - an additional amount of thermal energy - 376.7 Gcal or $20.2 \%$; ecological - reduction of natural gas consumption -47.7 thousand $\mathrm{m}^{3}$, reduction into the atmosphere of $\mathrm{CO}_{2}$ and $\mathrm{NO}_{\mathrm{x}}$ emissions 92.6 tons and 0.101 tons, respectively; economic: reduction of payment for thermal energy - 721.3 thousand UAH; the payback period of the event is 5 years.

5 . The research results showed such properties of the proposed method for evaluating the effectiveness of energy-saving measures, such as: high information content of the results, providing the possibility of multicriteria optimization of the parameters of heat supply systems and heat consumption of the research object, ability to improve by increasing the number of studied performance indicators.

\section{References}

1. The Covenant of Mayors for Climate and Energy Reporting Guidelines / Covenant of Mayors \& Mayors for climate and energy (2016). Adapt Offices and the Joint Research Centre of the European Commission, 78. [in English].

2. Alibekova, A., Shaimerdenova, G., Agilbaeva, M. (2013). Ecologica problems of thermal power plants. Journal of Industrial Technology and Engineering, № 4(09), 40-44. [in English].

3. Varlamov, G., Didik, I. (2016). The main features of the implementation of the principle of environ-mental equilibrium on the ecological object. [Osnovni osoblyvosti realizaciyi pryncypu ekolohichnoyi rivno-vahy na ekolohichnomu ob'yekti]. Young scientist: scientific journal,1, P.3, 104-107. [in Ukrainian].

4. Doroguntsov, S., Kotsenko, K., Hvesik, M. (2005). Ecology: a textbook. [Ekolohiia: Pidruchnyk]. KNEU, 104. [in Ukrainian].

5. Prutska ,O., Fedik, O. (2012). The current state and problems of development of alternative energy in Ukraine [Suchasnyi Stan Ta Problemy Rozvytku Alternatyvnoi Enerhetyky V Ukraini]. VNAU, 1(56). Vol. 2,158-164. [in Ukrainian].

6. Sten, I. (2018). Analysis of constructions of hot water supply systems used in Ukraine. [Analiz konstrukcij geliosistem garyachogo vodopostachannya, yaki vikoristovuyutsya $\mathrm{V}$ Ukrayini]. P. 1, 131-132. [in Ukrainian].

7. Kupalova, I. (2016). Determination of emissions by stationary sources. [Vyznachennia Obsiahiv Vykydiv Statsionarnymy Dzherelamy]. Visnyk. Officially about taxes, 32 (889), 32-37. [in Ukrainian]. 
8. HERZ Smart Comfort: remote control of home comfort [distancionnoe upravlenie komfortom doma]. [electronic resource]. https://is.gd/uNBsR0. [in Russian].

9. Flat solar collectors Logasol SKT 1.0. Buderus Ukraine [Ploski Soniachni Kolektory Logasol SKT 1.0. Buderus Ukraina]. [electronic resource]. https://is.gd/uNBsR0. [in Ukrainian].

\section{Література}

1. The Covenant of Mayors for Climate and Energy Reporting Guidelines / Covenant of Mayors \& Mayors for climate and energy // Adapt Offices and the Joint Research Centre of the European Commission, 2016. - $78 \mathrm{~s}$.

2. Alibekova A., Shaimerdenova G., Agilbaeva M. Ecolodica problems of thermal power plants // Journal of Industrial Technology and Engineering, 2013. Вип. 4(09). - Рp. 40-44.

3. Варламов Г.Б., Дідик І.С. Основні особливості ре-алізації принципу екологічної рівноваги на екологічному об'єкті // Молодий вчений: наук. журнал. - Херсон, 2016. - № 1, Ч. 3. - С. 104-107.

4. Дорогунцов С.I., Коценко К.Ф., Хвесик М.А.. Екологія: підручник. КНЕУ, 2005. 104 с.

5. Пругська О.О., Федик О.Ю. Сучасний стан та проблеми розвитку альтернативної енергетики в Україні // Збірник наукових праць ВНАУ, 2012. Вип. 1 (56). т. 2. С. 158-164.

6. Штен І. Аналіз конструкцій геліосистем гарячого водопостачання, які використовуються в Україні //,Збірник тез Міжнародної студентської науково-технічної конференції Природничі та гуманітарні науки. Актуальні питання., 2018. - T. 1. - C. 131-132.

7. Купалова I. Визначення обсягів викидів стаціонарними джерелами // Вісник. Офіційно про податки, 2016. Вип. 32 (889). C. 32-37.

8. HERZ Smart Comfort: дистанционное управление комфортом дома [електронний ресурс] / режим доступу: https://is.gd/uNBsR0.

\section{КОМПЛЕКСНА ОЦНКА ЕФЕКТИВНОСТІ ЕНЕРГОЗБЕРІГАЮЧИХ ЗАХОДІВ В СФЕРІ ТЕПЛОПОСТАЧАННЯ ЗАКЛАДІВ ОСВІТИ}

А.П. Полив'янчук ${ }^{1}$, С.В. Романенко ${ }^{1}$, Р.А. Семененко ${ }^{1}$, Л.В. Семененко ${ }^{2}$, К.А. Сськова ${ }^{1}$

${ }^{1}$ Харківський національний університет міського господарства імені О.М. Бекетова, Україна

${ }^{2}$ Національний технічний університет «Харківський політехнічний інститут», Україна

Роботу присвячено вирішенню актуальної наукової проблеми - підвищенню інформативності методів оиінки ефективності енергозберігаючих заходів у сферах теплопостачання і теплоспоживання. Мета досліджень полягала у створенні та впровадженні методу багатокритеріальної очінки ефективності енергозберігаючих заходів при теплозабезпеченні будівель. В якості критеріїв оиінки ефективності досліджуваних заходів за ичим методом використовувались показники: 1) енергетичного ефекту - абсолютна та відносна величини збереженої теплової енергії; 2) екологічного ефекту - кількість збереженого палива, зменшення викидів парникових газів $i$ забруднюючих речовин в атмосферу; 3) економічного ефект у - вартість економії теплової енергії та палива. Практична реалізація створеного методу була здійснена на базі 2-х натурних об'єктів: №1 - 3-поверхового фрагменту адміністративної будівлі ХНУМГ ім. О.М. Бекетова із загальною опалювальною площею $225 \mathrm{M}^{2}$ та №2 будівлі КЗ «Харківський палац дитячої та юнаџької творчості» із загальною опалювальною площею понад 13700

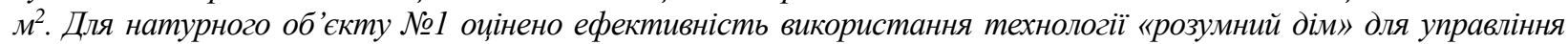
тепловими режимами приміщень будівлі за допомогою автоматизованої системи HERZ Smart Comfort (HSC). Для натурного об'єкту №2 очінено ефективність використання двох енергозберігаючих заходів: управління тепловими режимами приміщень будівлі системою HSC та використання альтернативного джерела теплопостачання - геліосистеми, яка складається з 180 сонячних колекторів. Результати досліджень показали такі властивості запропонованого методу оиінки ефективності енергозберігаючих заходів, як: висока інформативність результатів, щзо забезпечує можслвість багатокритеріальної оптимізації параметрів систем теплопостачання та теплоспоживання об'єктів досліджень, здатність до вдосконалення за рахунок збільшення кількості досліджуваних показників ефективності.

Ключові слова: теплопостачання, опалювальна площуа, енергозберігаючі заходи, ефективність, комплексна оцінка, натурний об'єкт, заклад освіти. 